\title{
Minicircle kDNA Microheterogeneity in Endotrypanum Indicate Diversity within this Genus
}

\author{
Antonia MR Franco, Gérzia MC Machado, Célia FS Moreira, \\ Gabriel Grimaldi Jr ${ }^{+}$
}

\author{
Departamento de Imunologia, Instituto Oswaldo Cruz, Av. Brasil 4365, 21045-900 Rio de Janeiro, RJ, Brasil
}

A comparison of $k D N A$ restriction-endonuclease fragment patterns from strains representing selected Endotrypanum zymodemes was done by schizodeme analysis. As the degree of heterogeneity within mini-circles varied among species or strains of Endotrypanum, the fingerprint obtained with each of the restriction enzymes was unique for each of these parasites. The data have revealed that this trypanosomatid genus is much more complex than it was originally thought to be.

Key words: Endotrypanum - Trypanosomatidae - minicircle kDNA analysis

Parasitic protozoa of the genus Endotrypanum (Kinetoplastida: Trypanosomatidae) are biologically diverse group of microorganisms in that infection appears to be restricted to edentates. These parasites have three distinct motile flagellated stages in their life cycle: promastigote (that lives within the alimentary tract of the sand fly vector), epimastigote and trypomastigote (the later stage residing within erythrocytes of their vertebrate hosts, sloths of the genera Choloepus and Bradypus) forms (Shaw 1992).

In nature, Endotrypanum spp. are probably transmitted by the bite of infected phlebotomine sand flies (Diptera: Psychodidae) (Shaw 1964). Arias et al. (1985) identified E. schaudinni infection in sand flies and sloths captured in the Amazon region of Brazil. Studies using kinetoplast DNA probe for detecting the parasite in sand flies also demonstrated Endotrypanum in Lutzomyia shannoni, L. umbratilis and L. anduzei (Rogers et al. 1988). However, infections with other biologically distinct trypanosomatid protozoa, such as Leishmania and Trypanosoma are also found in sloths and in sand flies in Neotropical forests (Shaw 1992).

Taxonomic studies of Endotrypanum isolates from the Americas indicate genetic diversity among these microorganisms (Franco \& Grimaldi Jr 1999). Since the description of the genus, the num-

\footnotetext{
+Corresponding author: Fax: +55-21- 280.1589. E-mail: grimaldi@ioc.fiocruz.br Received 16 August 1999 Accepted 10 January 2000
}

ber of strain variants of this parasite has increased, although only two species have been described. As a result of using numerical zymotaxonomy for classifying these organisms (Franco et al. 1996), the taxonomic horizon of Endotrypanum spp. has been widened.

Here we have studied minicircle kinetoplast DNA (kDNA) polymorphism (population heterogeneity) among references strains and Endotrypanum isolates from the Brazilian Amazon region, by analysis of restriction-endonuclease fragment patterns of kDNA (Grimaldi Jr et al. 1992). Minicircle sequences have been used as biochemical markers in classification of Leishmania using kDNA fingerprinting (Grimaldi Jr et al. 1992) or hybridization (Rogers et al. 1988).

The genus Endotrypanum, analyzed in this study (identification of the strains, their geographic origin and the source of stocks used are given in the Table), may represent an heterogeneous complex of parasite species or strain variants, as classified by zymotaxonomy (Franco et al. 1996). A comparison of kDNA fragment patterns from strains representing selected Endotrypanum zymodemes and Leishmania species (that are also frequently found in sloths) was done by schizodeme analysis of endonuclease Alu I, Hinf I, Msp I, and Taq I, digests of kDNAs, fractioned by gradient acrylamid gel electrophoresis, using the method described previously (Grimaldi Jr et al. 1992). With these digests, sequence microheterogeneity in mini-circle DNA was revealed and could be compared between different parasites.

As the degree of heterogeneity within minicircles varied among species or strains of Endotrypanum, the fingerprint obtained with each 
TABLE

Origin and identification of the Endotrypanum stocks and other reference strains employed in this study

\begin{tabular}{|c|c|c|c|}
\hline Stock & Designation $^{a}$ & Species $^{b}$ (zymodeme/group) ${ }^{c}$ & Geographic origin \\
\hline \multicolumn{4}{|c|}{ Endotrypanum strains } \\
\hline E01 & $\mathrm{MCHO} / \mathrm{BR} / 89 / \mathrm{RO} 9627^{\mathrm{a}}$ & Endotrypanum sp. (EZ01/A) & Brazil, Rondônia \\
\hline E02 & $\mathrm{MCHO} / \mathrm{BR} / 89 / \mathrm{RO} 1635^{\mathrm{a}}$ & Endotrypanum sp. (EZ01/A) & Brazil, Rondônia \\
\hline E03 & $\mathrm{MCHO} / \mathrm{BR} / 89 / \mathrm{RO} 1634^{\mathrm{a}}$ & Endotrypanum sp. (EZ01/A) & Brazil, Rondônia \\
\hline E05 & $\mathrm{MCHO} / \mathrm{BR} / 89 / \mathrm{RO} 1602^{\mathrm{a}}$ & Endotrypanum sp. (EZ01/A) & Brazil, Rondônia \\
\hline E06 & $\mathrm{MCHO} / \mathrm{BR} / 89 / \mathrm{RO} 1471^{\mathrm{a}}$ & Endotrypanum sp. (EZ01/A) & Brazil, Rondônia \\
\hline E18 & $\mathrm{MCHO} / \mathrm{BR} / 85 / \mathrm{IM} 2384^{\mathrm{a}}$ & Endotrypanum sp. (EZ01/A) & Brazil, Rondônia \\
\hline E11 & $\mathrm{MCHO} / \mathrm{CR} / 62 / \mathrm{A}-9^{\mathrm{b}}$ & E. monterogeii (EZ01/A) & Costa Rica \\
\hline E09 & MBRA/PA/00/415P01 & Endotrypanum sp. (EZ01/A) & Panama \\
\hline E31 & $\mathrm{MCHO} / \mathrm{BR} / 85 / \mathrm{IM} 2259^{\mathrm{c}}$ & Endotrypanum sp. (EZ02/A) & Brazil, Pará \\
\hline E22 & $\mathrm{MCHO} / \mathrm{BR} / 89 / \mathrm{IM} 3606^{\mathrm{c}}$ & Endotrypanum sp. (EZ03/A) & Brazil, Rondônia \\
\hline E36 & MCHO/BR/89/IM3603 ${ }^{\mathrm{c}}$ & Endotrypanum sp. (EZ03/A) & Brazil, Rondônia \\
\hline E14 & MCHO/BR/80/M6159 & E. schaudinni $\quad$ (EZ06/B) & Brazil, Pará \\
\hline E32 & $\mathrm{MCHO} / \mathrm{BR} / 85 / \mathrm{IM} 2380^{\mathrm{a}}$ & Endotrypanum sp. (EZ08/B) & Brazil, Rondônia \\
\hline E17 & $\mathrm{MCHO} / \mathrm{BR} / 85 / \mathrm{IM} 2382^{\mathrm{a}}$ & Endotrypanum sp. (EZ09/B) & Brazil, Rondônia \\
\hline E33 & $\mathrm{MCHO} / \mathrm{BR} / 85 / \mathrm{IM} 2393^{\mathrm{a}}$ & Endotrypanum sp. (EZ11/B) & Brazil, Rondônia \\
\hline E12 & $\mathrm{MCHO} / \mathrm{BR} / 88 / \mathrm{M} 11602^{\mathrm{c}}$ & E. schaudinni $\quad$ (EZ12/C) & Brazil, Pará \\
\hline \multicolumn{4}{|c|}{ Leishmania strains } \\
\hline L565 & MHOM/BR/75/M4147 & Leishmania guyanensis & Brazil, Pará \\
\hline L894 & MHOM/EC/87/G-07 & L. panamensis & Ecuador, Pichincha \\
\hline L888 & MCHO/EC/82/LSP1 ${ }^{\mathrm{b}}$ & L. equatorensis & Ecuador, Guayas \\
\hline
\end{tabular}

a: designations: host [ $\mathrm{M}=$ Mammalia: BRA: Bradypus infuscatus; CHO: Choloepus sp. $\left({ }^{\mathrm{a} C}\right.$. juruanus Lönnberg 1942; ${ }^{\mathrm{b}}$ C. hoffmani; ${ }^{\mathrm{c}} \mathrm{C}$. didactylus)/country of origin/year of isolation/original code]; $b$ : stock identification was established by enzyme activities (Medina-Acosta et al. 1994) and monoclonal antibodies (Franco et al. 1997) analyses; c: Endotrypanum zymodeme/phenetic group classified by enzyme electrophoresis according to their enzyme patterns and numerical analyses (Franco et al. 1996).

of the restriction enzymes was unique for each of these parasites. Overall, the stocks representing different zymodemes could be discriminated into distinct parasites, according to the major sequence classes (minicircle fragments or digests) released by the restriction enzymes tested. Moreover, sequence microheterogeneity in minicircle DNA was detected among isolates of Endotrypanum sp. from C. juruanus collected at the same locality in the State of Rondônia, Brazil, with Taq I (Figure) and other enzymes (data not shown). These strains (E01, E02, E03, E05, E06 and E18) revealed schizodeme profiles that were distinguishable from those seen with other parasite strains (E11 and E09) clustered into the same zymodeme (Franco et al. 1996).

The taxonomy of Endotrypanum spp. is still controversial. Since the original description, only two species have been named as E. schaudinni Mesnil and Brimont, 1908 and E. monterogeii Shaw, 1969. However, E. monterogeii is phenotypically related to E. schaudinni (which was isolated from C. didactylus in Brazil), since ultrastructural and biochemical parameters were similar (Croft et al. 1980), in contrast to the description by
Shaw (1969), who reported serological differences between these species. Lopes et al. (1990), also grouped both species in the same cluster by comparison of nuclear DNA restriction fragment patterns.

As a result of using numerical zymotaxonomy for classifying these organisms, the data indicated that (i) E. schaudinni represents an heterogeneous complex of parasite strain variants (EZ05, EZ06, EZ12) and (ii) the E. monterogeii reference strain, which was isolated from $C$. hoffmanni in Costa Rica, is phenetically closely related to other parasites from Brazil and Panama (Franco et al. 1996). In this study, the minicircle kDNA analysis was able to confirm the polymorphism in E. schaudinni, as well as to differentiate the heterogenous population of parasites that were clustered into the same zymodeme (EZ01).

In conclusion, minicircle kinetoplast DNA polymorphism analysis appears to be a typing system useful for epidemiologic and taxonomic studies of Endotrypanum, being sensitive to differentiate distinct zymodemes belonging to this genus while simultaneously revealing considerable molecular diversity. 


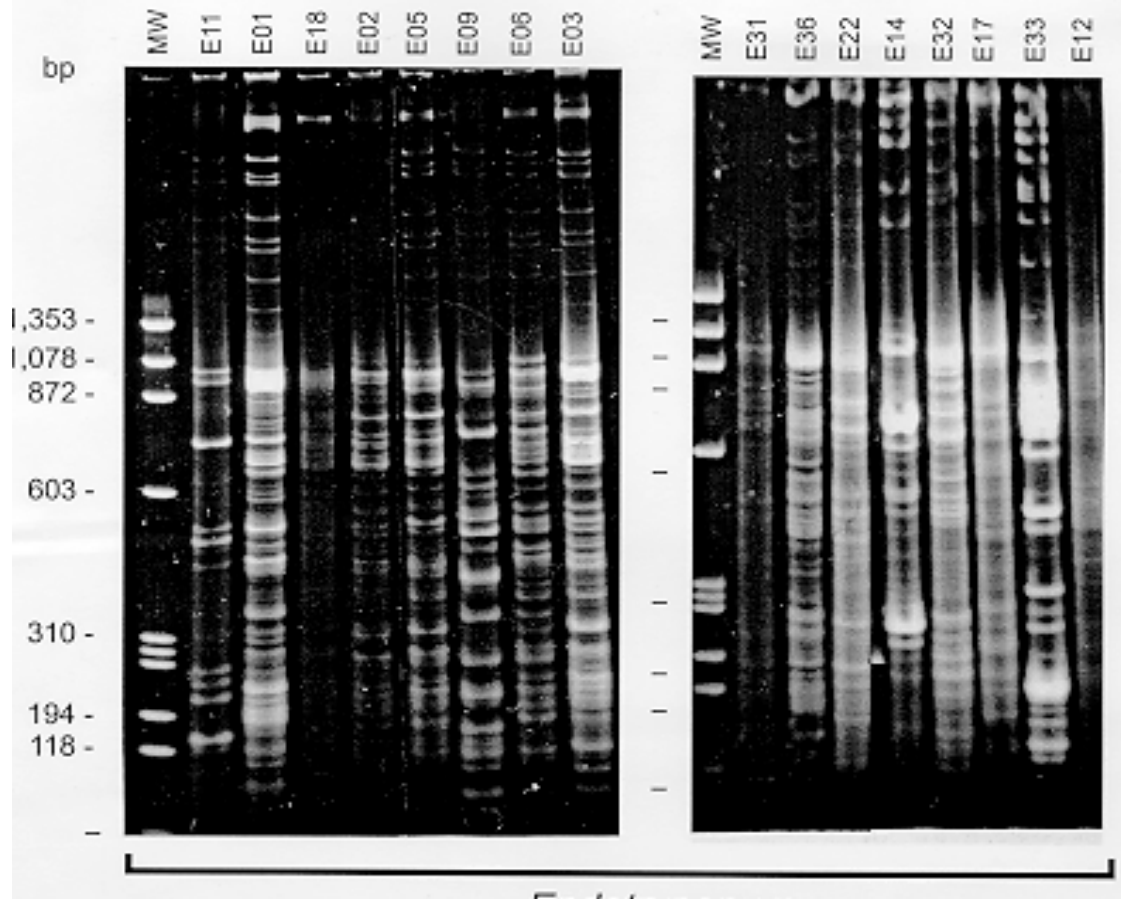

Endotrypanum

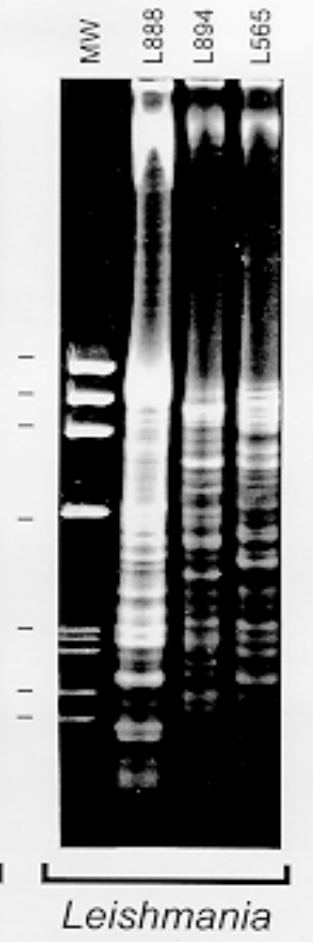

Acrylamide gradient (5-12\%) gel electrophoresis comparison of kDNA fragment patterns, generated with the restriction enzyme Taq I, among representative strains complexes of Endotrypanum and selected Leishmania species. The stock codes of the strains studied by kDNA analysis are indicated above the lanes and information on their origin is given in the Table. The apparent sizes of kDNA fragments are estimated relative to fragments from a Hae III digest of 0 x 174 RF DNA and their molecular weights are indicate in base pairs (bp) beside the figures. The linearized minicircles migrate at about $0.8 \mathrm{~kb}$ and, in some lanes, the minicircle digests appear as bands (ladders) between 0.05 and $0.07 \mathrm{~kb}$.

\section{REFERENCES}

Arias JR, Miles MA, Naiff RD, Póvoa MM, de Freitas RA, Biancardini CB, Castellon EG 1985. Falagellate infections of Brazilian sand flies (Diptera: Psychodidae): isolation in vitro and biochemical identification of Endotrypanum and Leishmania. Am J Trop Med Hyg 34: 1096-1108.

Croft SL, Chance ML, Gardener P 1980. Ultrastructure and biochemical characterization of stocks of Endotrypanum. Ann Trop Med Parasitol 74: 585-589.

Franco AMR, Grimaldi Jr G 1999. Characterization of Endotrypanum (Kinetoplastida: Trypanosomatidae), a unique parasite infecting the Neotropical tree sloths (Edentata). Mem Inst Oswaldo Cruz 94: 261-268.

Franco AMR, Machado GMC, Naiff RD, Moreira CFS, McMahon-Pratt D, Grimaldi Jr G 1997. Characterization of Endotrypanum parasites using specific monoclonal antibodies. Mem Inst Oswaldo Cruz 92: 63-68.

Franco AMR, Momen H, Naiff RD, Moreira CFS, Deane MP, Grimaldi Jr G 1996. Enzyme polymorphism in Endotrypanum and numerical analysis of isoenzyme data. Parasitology 113: 39-48.

Grimaldi Jr G, Kreutzer RD, Hashiguchi Y, Gomez EA, Mimory T, Tesh RB 1992. Description of Leishmania equatorensis sp. n. (Kinetoplastida: Trypanoso- matidae), a new parasite infecting arboreal mammals in Ecuador. Mem Inst Oswaldo Cruz 87: 221-228.

Lopes AHCS, Iovannisci D, Petrillo-Peixoto M, McMahon-Pratt D, Beverley SM 1990. Evolution of nuclear DNA and the occurrence of sequences related to new small chromosomal DNAs in the trypanosomatid genus Endotrypanum. Mol Biochem Parasitol 40: 151-162.

Medina-Acosta E, Franco AMR, Jansen AM, Sampol M, Nevés N, Pontes-de-Carvalho L, Grimaldi Jr G, Nussenzweig V 1994. Trans-sialidase and sialidase activities discriminate between morphologically indistinguishable trypanosomatids. Eur J Biochem 225: 333-339

Rogers WO, Burnheim PF, Wirth DF 1988. Detection of Leishmania within sand flies by kinetoplast DNA hybridization. Am J Trop Med Hyg 39: 434-439.

Shaw JJ 1964. A possible vector of Endotrypanum schaudinni of the sloth Choloepus hoffmanni in Panama. Nature 201: 417-418.

Shaw JJ 1969. The Haemoflagellates of Sloths, London School of Hygiene and Tropical Medicine, Memoir No. 13, HK Lewis and Co., London, 132 pp.

Shaw JJ 1992. Endotrypanum, a unique intraerythrocytic flagellate of New World tree sloths. An evolutionary link or an evolutionary backwater? Ciênc Cult 44: 107-116. 